\title{
Inheritance of Reverse Margo Seedcoat Pattern and Allelism between the Genes $J$ for Seedcoat Color and $L$ for Partly Colored Seedcoat Pattern in Common Bean
}

\author{
Mark J. Bassett ${ }^{1}$ \\ Department of Horticultural Sciences, University of Florida, Gainesville, FL 32611-0690 \\ Rian Lee, ${ }^{2}$ Tim Symanietz, ${ }^{3}$ and Phillip E. McClean ${ }^{3}$ \\ Department of Plant Sciences, North Dakota State University, Fargo, ND 58105-5051
}

AdDitional IndeX words. Phaseolus vulgaris, inheritance, seedcoat genetics, RAPD markers

\begin{abstract}
Two common bean (Phaseolus vulgaris L.) genes, $J$ (modifies seedcoat color and pattern) and $L$ (modifies partly colored seedcoat pattern), were tested for allelism using genetic tester stocks. Those stocks have a common genetic background by backcrossing to the recurrent parent, Florida dry bean breeding line 5-593, that has black self-colored seeds and purple flowers due to the genotype $T P[C r] Z J G B V R k$. Specifically, the $L$ gene from 'Thuringia' and the $l^{\text {ers }}$ gene from 'Early Wax' were tested for allelism with the $j$ gene from various genetic tester stocks. $L$ was found to be identical with $j$, but $l^{\text {ers }}$ was a different allele at $J$. We propose the gene symbols $J$ (formerly $l$ ), $j$ (formerly $L$ ), and $j^{\text {ers }}$ (formerly $l^{\text {ers }}$ ). The seedcoat genotype of 'Thuringia' was found to be $t P C z j g b v^{\text {lae }} r k^{\text {d }}$. A new seedcoat pattern called reverse margo was found to be determined by the genotype $T / t z / z j / j^{\text {ers }}$ in a $P C G B V$ genetic background. A randomly amplified polymorphic DNA marker was developed for the $j$ gene (formerly $L$ ) from 'Thuringia' using bulk segregant analysis in an $\mathrm{F}_{2}$ population segregating for $j$ vs. $J$ in a $t z$ genetic background, i.e., from the cross $t z j \times t z J$ in $\mathrm{BC}_{1}$ to 5 593. The linkage distance between marker $\mathrm{OL} 4_{525}$ and $j$ was determined to be $1.2 \mathrm{cM}$. In a population segregating for $J$ and $j^{\text {ers }}$, the distance between the marker and $j^{\text {ers }}$ was determined to be $4.7 \mathrm{cM}$. The utility of marker $0 \mathrm{OL} 4_{525}$ is limited primarily to the Middle American gene pool.
\end{abstract}

In common bean (Phaseolus vulgaris), the $t$ allele of the Tlocus expresses two pleiotropic effects, viz., partly colored seedcoats and white flowers (Leakey, 1988). The shape of the partly colored seedcoat patterns is controlled by interactions of $t$ with the genes $Z$, L, Bip , and J (Bassett, 1994a, 1996a; Lamprecht, 1940; Schreiber, 1940). The gene $J$ is also a major locus for seedcoat color, where the recessive $j$ allele usually expresses a paler version of the color expressed by the allele $J$, a duller (less shiny) seedcoat, and a loss of color in the corona zone of the seedcoat (Bassett, 1996a; Prakken, 1970, 1972).

At the limiter locus, the dominant $L$ allele contracts partly colored seedcoats with respect to the pattern with $l$, which has no effect on partly colored patterns (Schreiber, 1940). For English language descriptions and recent illustration of the patterns, see Bassett (1994a, 1996a) for the $t Z j$ interaction, Bassett (1996b) for the $t$ Z/z Bip/bip bipunctata interactions, and Bassett (1997) for the $t Z / z l / /^{\text {ers }}$ interactions. A brief review of the genetics of partly colored patterns (with illustrations) was published (Bassett and McClean, 2000) and is available on line: http://beangenes.cws.ndsu.nodak.edu/ papers/partlycoloredreview.pdf.

Recently, a study that demonstrated the hilum ring factor gene $D$ was allelic with the zonal pattern gene $Z$ (Bassett et al., 1999) also suggested a previously unrecognized genetic relationship between $J$ and $L$. Complete $\mathrm{F}_{2}$ and $\mathrm{F}_{3}$ genetic analysis of a cross used in that

Received for publication 12 Apr. 2001. Accepted for publication 19 Sept. 2001 This research was supported by the Florida Agricultural Experiment Station and a T-STAR grant, and approved for publication as journal series no. R-08030. We thank Hallie Smith and Rachel Stevens, Graphics Dept., Office of Instructional Resources, Univ. of Florida, Gainesville, for preparing the illustrations used in this paper. The cost of publishing this paper was defrayed in part by the payment of page charges. Under postal regulations, this paper therefore must be hereby marked advertisement solely to indicate this fact.

'Professor.

${ }^{2}$ Research specialist.

${ }^{3}$ Undergraduate student. study between two genetic tester stocks, $t z$ virgarcus $\mathrm{BC}_{3} 5-593$ and $d j$ margo $\mathrm{BC}_{3}$ 5-593, revealed three phenotypes/genotypes: 1) virgarcus for $t z J, 2$ ) a pattern very similar to "weak virgarcus" for $t z J / j$, and 3) white for $t z j$. These exhibited striking similarities with the results of Bassett (1997), who observed the virgarcus seedcoat pattern for $t z l$, weak virgarcus for $t z l / l^{\text {ers }}$, and white for $t z l^{\text {ers }}$. The genetic experiments reported below tested the hypothesis that $j, L$, and $l^{\text {ers }}$ are alleles at a putatively common locus and that $j$ and $L$ are identical alleles. The paper will also present evidence for inheritance of a new seedcoat pattern "reverse margo."

\section{Materials and Methods}

DeVELOPMENT OF GENETIC TESTER STOCKS. Florida dry bean breeding line 5- 593 has the shiny, unpatterned, black seedcoat genotype TlBip P $[C r] Z J G B$ VRkAsp (Bassett, 1998a, 1999) and has been used for many years as a recurrent parent in a program to produce genetic tester stocks. These stocks contain one or more recessive marker genes backcrossed into 5-593 with selection against all other marker genes (Bassett, 1994b). Line 5-593 has colored (purple) flowers due to the genotype $T P V$ (Leakey, 1988).

Genetic tester stock $t z$ lers $^{\text {ers }}$ wite $\mathrm{BC}_{2}$ 5-593 was developed from the 'Early Wax' snap bean (Bassett and Blom, 1991), but the unusual genotype for white seedcoat in 'Early Wax' was determined later (Bassett, 1997). Genetic tester stock $t z j$ white $\mathrm{BC}_{3} 5-593$ was developed while testing the hypothesis of allelism between the genes $z$ and $d$ (Bassett et al., 1999). The development of the $t z$ virgarcus $\mathrm{BC}_{3}$ 5-593 genetic stock was described previously (Bassett, 1996b).

Allelism test Cross For $j$ AND $L$. The cross $t z j$ white $\mathrm{BC}_{3} 5-593$ $\mathrm{x} t z l^{\text {ers }}$ white $\mathrm{BC}_{3} 5-593$ was made in Fall 1998, and the $\mathrm{F}_{1}$ and $\mathrm{F}_{2}$ progenies were grown in the greenhouse in Winter 1999 and in the field in Spring 1999, respectively. Data were recorded on seedcoat color and pattern. 
DEVELOPMENT OF A RAPD MARKER FOR $L$. Seeds of the cultivar Thuringia (accession PHA 1105/86) were obtained from the Genebank at the Institut für Pflanzengenetik und Kulturpflanzenforschung, Gatersleben, D-06466, Germany. The seedcoat genotype of 'Thuringia' is $t P z L$ (Schreiber, 1940). 'Thuringia' has white flowers due to $t$ and pure white seedcoats due to the interaction of $z$ and $L$ with $t$ (Schreiber, 1940). In Fall 1994 'Thuringia' was crossed with $t z$ virgarcus $\mathrm{BC}_{3}$ 5-593, and the $\mathrm{F}_{2}$ was planted in the field in Spring 1995. Selection was made in $F_{2}$ for plants with white seed due to genotype $t z \mathrm{~L} /$-. True breeding progenies with $t z L / L$ were obtained in $\mathrm{F}_{4}$ and backcrossed to $t z$ virgarcus $\mathrm{BC}_{3}$ 5-593 in Fall 1996. The backcross $\mathrm{F}_{2}$ was planted in the field in Spring 1997, and data were recorded on segregation for seedcoat color and pattern (a 3:1 ratio was observed for white $(t z L /$ -) to virgarcus $(t z l / l)$, respectively). Remnant $\mathrm{BC}_{1}-\mathrm{F}_{2}$ seed was sent to North Dakota State University, Fargo. The population was grown out, and the procedures of Brady et al. (1998) were followed to identify a randomly amplified polymorphic DNA (RAPD) marker linked to $L$. Each bulk in the bulk segregant analysis procedure had eight individuals, and an $\mathrm{F}_{2}$ population of 79 individuals was used to estimate the linkage of $L$ with OL4. Linkage was determined by MapMaker 3.0 (Lander et al., 1987; Lincoln et al., 1992) software program. Further backcrosses of $t z L \mathrm{BC}_{1} 5-593$ to 5-593 were made to produce $t z \mathrm{LBC}_{2}$ and $\mathrm{BC}_{3} 5-593$.

To determine the full genotypes for seedcoat color and to confirm the work of Schreiber (1940), 'Thuringia' was crossed to 5-593 and a series of genetic tester stocks: $c^{\mathrm{u}} \mathrm{BC}_{3}$ 5-593 (cartridge buff seedcoat), $j$ margo $\mathrm{BC}_{3}$ 5- 593, $t j$ marginata $\mathrm{BC}_{3} 5-503, t z j$ white $\mathrm{BC}_{3}$ 5-593, and $g b v \mathrm{BC}_{3}$ 5-593 (shamois seedcoat), $v \mathrm{BC}_{3}$ 5-593 (mineral brown seedcoat), and $c^{\mathrm{u}} b v r k^{\mathrm{d}} \mathrm{BC}_{1} 5-593$ (dark red kidney seedcoat). In the latter stock the $r k^{\mathrm{d}}$ gene was derived from 'Montcalm' dark red kidney bean (Bassett, unpublished data). The $\mathrm{F}_{1}$ progeny were grown in the greenhouse in Winter 2000 and the $F_{2}$ in the field in Spring 2000. Data were recorded on flower color and seedcoat color and pattern.

\section{Results and Discussion}

The $\mathrm{F}_{1}$ progeny from the cross $t z j$ white $\mathrm{BC}_{3} 5-593 \times t z z^{\text {ers }}$ white $\mathrm{BC}_{3} 5-593$ had seeds with white seedcoats, and the $\mathrm{F}_{2}$ progeny were true breeding for white seedcoats (data not presented). The failure of complementation between $j$ and $l^{\text {ers }}$, which would have expressed partly colored seedcoats with virgarcus pattern, supports the hypothesis that $j$ and $l^{\text {ers }}$ are allelic because the genotype of virgarcus is $t z l$ (Schreiber, 1940).

Before presenting test cross results with 'Thuringia,' we will present the correspondences of names of partly colored seeds used by Schreiber (1940) and those used in the present paper (Table 1). We will also discuss the differences in expression of various genotypes in eastern Germany and Florida. In the experience of the senior author, the colored zones in partly colored seedcoat patterns are more extensive when grown in the field during the spring and summer than when grown in the greenhouse in either fall or winter. Presumably, the higher temperatures and longer days of these seasons promote the greater extension of the colored patterns. The laciniata pattern (Fig. 1) of Schreiber (1940) expressed by $t / t Z / z L /$ $L$ when grown in eastern Germany has a tendency to express as a weak and unstable marginata pattern in Gainesville, Fla. The genotype $t / t z / z L / l$ expresses as erasa (pure white) in eastern Germany, but as a weak laciniata or a caruncula dot or two small dots (the larger one at the caruncula and smaller at the micropyle) in Gainesville, Fla. The phrase "weak laciniata" means a smaller
Table 1. Reconciliation of gene symbols and names of partly colored seedcoat patterns of common bean as expressed in eastern Germany (Schreiber, 1940) or Florida (Bassett et al., present paper) for the $\operatorname{cross} t Z l(J) \times t z L(j)$.

\begin{tabular}{lll}
\hline \hline Genotypes & \multicolumn{2}{c}{ Phenotype names } \\
\cline { 2 - 3 } Schreiber $(L=j)^{\mathrm{z}}$ & Schreiber & Bassett \\
\hline$Z / Z L / L(j / j)$ & Marginata & Marginata \\
$Z / Z L / l(J / j)$ & Ambigua A & "Ambigua"y \\
$Z / Z l / l(J / J)$ & Expansa & Expansa (self-colored) \\
$Z / z L / L(j / j)$ & Laciniata & "Laciniata" (unstable marginata) \\
$Z / z L / l(J / j)$ & Intermedia & Intermedia" \\
$Z / z l / l(J / J)$ & Ambigua B & Ambigua \\
$z / z L / L(j / j)$ & Erasa & Pure white \\
$z / z L / l(J / j)$ & Erasa & Laciniata or two dots $($ Caruncula dot) \\
$z / z l / l(J / J)$ & Restricta & Virgarcus or arcus
\end{tabular}

zThe hypothesis of this paper is that the $L$ gene of Schreiber (1940) is identical to the $j$ gene (Prakken, 1970).

${ }^{y}$ For genotype $Z / Z J / j$, pattern is often restricted to about half colored and half white.

${ }^{x}$ Genotype $Z / Z J / J$ with $t / t$ can also express self-colored seedcoats in the 5-593 genetic background.

${ }^{\mathrm{w}}$ Genotype $Z / z$ j/j expresses more extensively in Florida than in eastern Germany, often expressing a weakly expressed and unstable marginata pattern.

${ }^{v}$ Genotype $t / t Z / z J / j$ expresses Schreiber's (1940) intermedia (Fig. 2A). Genotype $t / t Z / z j^{\text {ers }} / j^{\text {ers }}$ expresses a more extensive intermedia pattern (Fig. 2B) (Bassett, 1997).

${ }^{u}$ Genotype $z / z \mathrm{~J} / \mathrm{j}$ produces partly colored pattern at Gainesville, usually only a caruncula dot, but sometimes an additional smaller dot at the micropyle; or a thin caruncula stripe only.

the fibula arcs factor can restrict virgarcus to arcus (Bassett, unpublished data).

and thinner caruncula stripe than the ones illustrated by Schreiber (1940). Because of the similarities in appearance and the instability of expression, the $t / t Z / z L / L$ and $t / t z / z, L / l$ classes are usually combined for analysis. Because all the other evidence presented below supports the hypothesis that $L$ and $j$ are the same allele, we choose to attribute the differences in pattern expression listed in Table 1 to environmental effects rather than interpret them as evidence for a different allele at $J$ (formerly $L$ locus) in 'Thuringia' compared to the $j$ in genetic tester stock $j \mathrm{BC}_{3} 5-593$.

Schreiber (1940) created the name intermedia for the partly colored seedcoat pattern (Fig. 2A) with genotype $t / t Z / z$ L/l (Table 1).

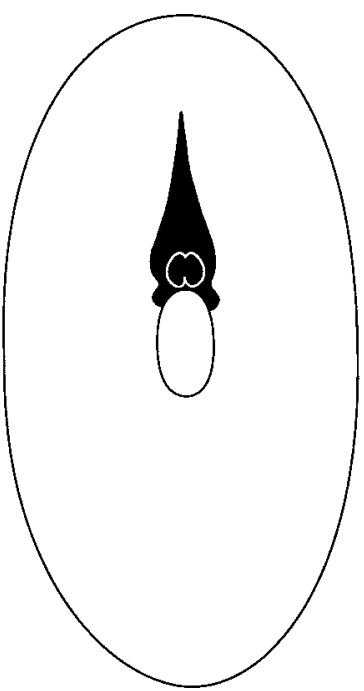
The present paper will demonstrate the allelism of $L$ with $j$ and $l$ with $J$. Bassett (1997) used the same name for a similar seedcoat pattern (Fig. 2B) with the genotype $t / t Z / z l^{\text {ers }} / l^{\text {ers }}$. The present paper will propose the new gene symbol $j^{\text {ers }}$ for $l^{\text {ers }}$, based on the allelism of the $J$ and $L$ loci demonstrated below.

When 'Thuringia', the source of the $L$ gene of Schreiber (1940), was crossed with $j$ margo $\mathrm{BC}_{3}$ 5-593, the $F_{1}$ progeny showed margo

Fig. 1. A ventral view of the laciniata pattern of partly colored seedcoat expressed by genotype $t / t Z / z j / j$ (where $j$ was formerly L). 
(A)
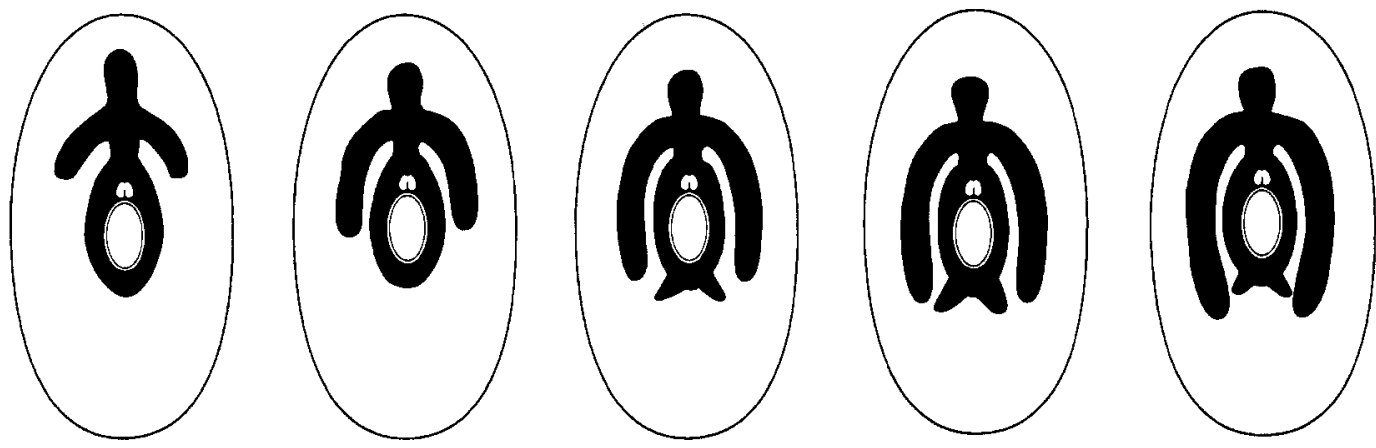

(B)
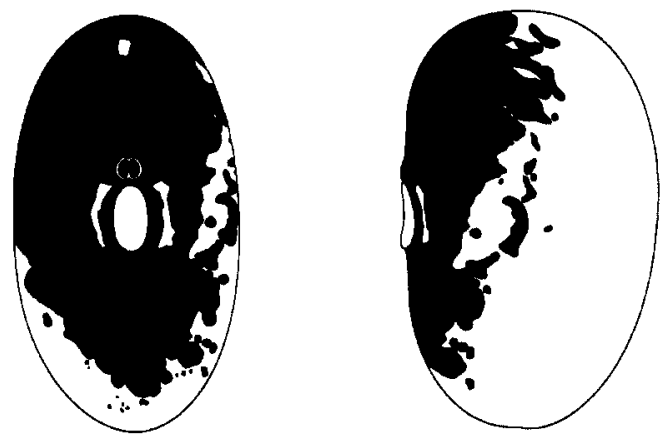

Fig. 2. (A) Five ventral views showing the range of expression of the intermedia pattern of partly colored seedcoat expressed by genotype $t / t Z / z, J / j$ and (B) a ventral view (left seed) and a side view (right seed) of the intermedia pattern of partly colored seedcoat expressed by the genotype $t / t Z / z j^{\text {ers }} / j^{\text {ers }}$ (where $j^{\text {ers }}$ was formerly $l^{\text {ers }}$ ).

Table 2. Segregation for seedcoat patterns (with genotypes) of common bean in $\mathrm{F}_{2}$ from test crosses of 'Thuringia' $\left(t P C z j g b v^{\text {lae }} r k^{\mathrm{d}}\right) \mathrm{x}$ various genetic stocks, where the $j$ in 'Thuringia' was formerly $L$.

\begin{tabular}{|c|c|c|c|c|c|c|c|c|c|}
\hline \multirow[b]{3}{*}{$\begin{array}{l}\text { Genetic } \\
\text { stock }\end{array}$} & \multicolumn{6}{|c|}{ Segregation classes with genotypes ${ }^{z}$} & \multirow[b]{3}{*}{$\begin{array}{l}\text { Ratio } \\
\text { tested }\end{array}$} & \multirow[b]{3}{*}{$\chi^{2}$} & \multirow[b]{3}{*}{$P$} \\
\hline & \multicolumn{3}{|c|}{$T /-$} & \multicolumn{3}{|c|}{$t / t$} & & & \\
\hline & $\begin{array}{c}Z /-J /- \\
\text { Self- } \\
\text { colored }\end{array}$ & $Z /-j / j$ & $\begin{array}{c}z j \\
\text { Margo } \\
z \\
\end{array}$ & $\begin{array}{c}Z /-J /- \text { or } z / z J /- \\
\text { Partly } \\
\text { colored }^{\mathrm{y}}\end{array}$ & $\begin{array}{c}Z /-j / j \\
\text { Marginata } \\
\text { or laciniata }\end{array}$ & $\begin{array}{c}z j \\
\text { Pure } \\
\text { white }\end{array}$ & & & \\
\hline $5-593$ & $110^{\mathrm{x}}$ & 12 & 6 & 15 & 15 & 5 & $36: 9: 3: 10: 5: 1^{\mathrm{w}}$ & 16.3 & 0.006 \\
\hline$j \mathrm{BC}_{3} 5-593$ & & $52^{\mathrm{x}}$ & 17 & & 17 & 5 & $9: 3: 3: 1$ & 0.097 & 0.99 \\
\hline$t j \mathrm{BC}_{3} 5-593$ & & & & & $58^{\mathrm{x}}$ & 20 & $3: 1$ & 0.017 & 0.90 \\
\hline$t z j \mathrm{BC}_{3} 5-593$ & & & & & & $30^{\mathrm{x}}$ & & & \\
\hline
\end{tabular}

${ }^{\mathrm{z}}$ Margo $z$ has no color in the corona or hilum ring; margo pattern has loss of color in corona only.

yThis class combines self-colored, expansa, ambigua, virgarcus, and intermedia.

${ }^{x}$ The seedcoat phenotype of this class was the same as that of seed on $\mathrm{F}_{1}$ plants $\left(\mathrm{F}_{2}\right.$ seed $)$ from the test cross.

${ }^{\text {w} F o r ~ t h e ~ s e g r e g a t i o n ~ d a t a ~ a t ~} T$ and $Z$ (data combined over $\left.J / j\right), 110,18,15,20$ give $\chi^{2}(9: 3: 3: 1)=26.2, P<0.001$. The orthogonal contrasts are $\chi^{2}$ T $=1.082, P=0.30, \chi_{\mathrm{J}}^{2}=0.247, P=0.62$, and $\chi_{\mathrm{L}}^{2}=24.87, P<0.001$. The coupling phase linkage is $24.21 \pm 3.95 \mathrm{cM}$. With $T /-$, the segregation at $Z$ is 122 to $12, \chi^{2}(3: 1)=28.17, P<0.001$.

Table 3. Summary of seedcoat pattern expressions produced by all combinations of the genes $T, Z$, and $J$, including the recessive alleles $t, z, j$ ers and $j$.

\begin{tabular}{llll}
\hline \hline Genotypes & $J(l)$ & $j^{\text {ers }}\left(l^{\text {ers }}\right)$ & $j(L)$ \\
\hline$T Z$ & Unpatterned & Unpatterned & Margo \\
$T z$ & Unpatterned & Unpatterned & Margo $z$ \\
$t Z$ & Self-colored / expansa & Self-colored / expansa & Marginata \\
$t z$ & Virgarcus / arcus & White $^{z}$ & White $^{z}$ \\
\hline
\end{tabular}

${ }^{\mathrm{z}}$ All seedcoat color expression is suppressed. 
Table 4. Segregation for seedcoat patterns (with genotypes) of common bean in $\mathrm{F}_{2}$ from test crosses: 1 ) $t z L$ white $\left.\mathrm{BC}_{2} 5-593 \times 5-593,2\right) t z L$ white $\mathrm{BC}_{2} 5-593 \times t$ black $\left.\mathrm{BC}_{2} 5-593,3\right) t z j$ white $\mathrm{BC}_{3} 5-593 \times t$ black $\left.\mathrm{BC}_{2} 5-593,4\right) t z j^{\text {ers }}$ white $\left(j^{\text {ers }}\right.$ formerly $\left.l^{\text {ers }}\right) \mathrm{BC}_{3} 5-593 \times j$ margo $\mathrm{BC}_{3} 5-593$, and 5) $t z j{ }^{\text {ers }}$ white $\mathrm{BC}_{3} 5-593 \times t j$ marginata $\mathrm{BC}_{3} 5-593 .^{\mathrm{z}}$

\begin{tabular}{|c|c|c|c|c|c|c|c|c|c|c|c|c|}
\hline \multicolumn{3}{|c|}{$T /-$} & \multicolumn{7}{|c|}{$t / t$} & \multirow[b]{2}{*}{$\begin{array}{l}\text { Ratio } \\
\text { tested }\end{array}$} & \multirow[b]{2}{*}{$\chi^{2}$} & \multirow[b]{2}{*}{$P$} \\
\hline $\begin{array}{l}\text { Cross } \\
\text { no. }\end{array}$ & $\begin{array}{l}Z /-J /- \\
\text { Self- } \\
\text { colored }\end{array}$ & $\begin{array}{l}Z /-j / j \\
\text { Margo }\end{array}$ & $\begin{array}{l}z / z j / j \\
\text { Margo } \\
z\end{array}$ & $\begin{array}{c}Z /-J /- \\
\text { Self-c, } \\
\text { exp, amb }\end{array}$ & $\begin{array}{l}Z / z J / j \\
\text { Inter- } \\
\text { media }\end{array}$ & $\begin{array}{c}Z / Z j / j \\
\text { Marginata }\end{array}$ & $\begin{array}{c}z / z J / J \\
\text { Virgarcus } \\
\text { or arcus }\end{array}$ & $\begin{array}{c}Z / z j / j \text { or } z / z J / j \\
\text { Lacini or } \\
\text { carunc } \operatorname{dot}^{\mathrm{x}}\end{array}$ & $\begin{array}{l}z / z j / j \\
\text { Pure } \\
\text { white }\end{array}$ & & & \\
\hline$\overline{1}$ & 168 & 39 & 11 & 23 & 14 & 3 & 7 & 13 & 1 & $36: 9: 3: 5: 4: 1: 1: 4: 1$ & 7.60 & 0.47 \\
\hline 2 & & & & 57 & 41 & 15 & 14 & 34 & 10 & $5: 4: 1: 1: 4: 1$ & 4.911 & 0.43 \\
\hline 3 & & & & 35 & 43 & 12 & 12 & 36 & 5 & $5: 4: 1: 1: 4: 1$ & 7.406 & 0.19 \\
\hline & & & & $Z /-j^{\text {ers }} / j^{\text {ers }}$ & $Z /-j / j^{\text {ers }}$ & $Z /-j / j$ & \multicolumn{6}{|c|}{$z / z j /-\left(\right.$ or $\left.j^{\text {ers }} / j^{\text {ers }}\right)$} \\
\hline 4 & $222(16)^{\mathrm{w}}$ & 54 & 21 & 13 & 29 & $20^{\mathrm{v}}$ & & & 14 & $36: 9: 3: 3: 6: 3: 4$ & 11.001 & 0.09 \\
\hline 5 & & & & 69 & 146 & 63 & & & 95 & $3: 6: 3: 4$ & 1.002 & 0.80 \\
\hline
\end{tabular}

'The $L$ gene symbol is retained in the labels for the genetic stocks derived from 'Thuringia', but $L$ is replaced by $j$ (new symbol) in the column headings.

${ }^{\mathrm{y}}$ Self-c, exp, amb = self-colored, expansa, and ambigua pattern classes combined; the $Z / z \mathrm{~J} / \mathrm{j}$ genotype is not included in $\mathrm{Z} / \mathrm{-} / \mathrm{-}$.

${ }^{x}$ Lacini or carunc dot $=$ laciniata and caruncula dot classes combined (See Table 1 for details).

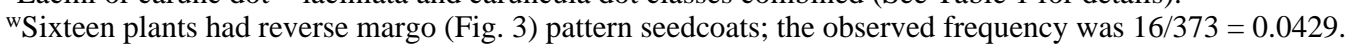

${ }^{\mathrm{v}}$ The marginata class and laciniata or caruncula dot class were combined.

the RAPD marker for $T$ mapped to linkage group B9 and the STS marker for $J$ mapped to linkage group B10 (McClean et al., unpublished data). Also, previously published data for segregation of $t$ and $j$ (same as mar, Bassett, 1996a) failed to show linkage between the genes (Bassett, 1994a, his Table 3), when there was no segregation at $Z$.

The complete seedcoat genotype of 'Thuringia' was determined by crossing it to a series of genetic tester stocks. The $\mathrm{F}_{1}$ progeny from the test cross 'Thuringia' $\mathrm{x} c^{\mathrm{u}} \mathrm{BC}_{3} 5-593$ produced seedcoats with black/bluish cartridge buff marbling with a secondary pattern in the light pattern area for light grayish blue/cartridge buff mottling (data not presented). Thus, there was double patterning. This is interpreted as a response of the $C$ gene in 'Thuringia' (Bassett, 2000). In the $F_{2}$ progeny from the cross 'Thuringia' $x$ 5- 593 there was no evidence of any $c$ gene effects (data not presented), confirming the test cross with $c^{\mathrm{u}}$. The $\mathrm{F}_{1}$ progeny from the test cross 'Thuringia' $\mathrm{x} g b v \mathrm{BC}_{3} 5-593$ produced seedcoats with violet/ shamois mottling and purple corona (data not shown). The violet color is beyond the scope of this paper and will not be discussed, but the shamois shows allelism for $g, b$, and $v$ (Prakken, 1970). The purple corona demonstrates the presence of the $v^{\text {lae }}$ allele (Bassett, 1995). Those results were confirmed in $F_{2}$ (data not presented). The $\mathrm{F}_{1}$ progeny from the test cross 'Thuringia' $\mathrm{x} v \mathrm{BC}_{3}$ 5-593 produced
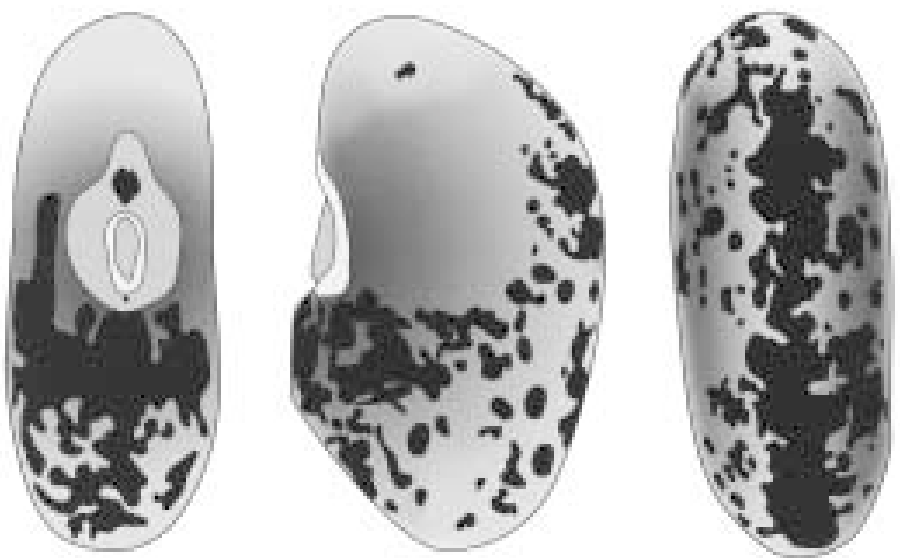

Fig. 3. A ventral view (left seed), a side view (middle seed), and a dorsal view (right seed) of the reverse margo seedcoat pattern expressed by genotype $T / \mathrm{t} z /$ $z j / j^{\text {ers }}$ (where $j^{\text {ers }}$ was formerly $l^{\text {ers }}$ ). mineral brown (with unstable, pale violet haze)/pale brown mottling. This result demonstrates that 'Thuringia' does not carry $R$, the gene for dominant red color (Prakken, 1972). The $F_{1}$ progeny from the test cross 'Thuringia' $\mathrm{x} c^{\mathrm{u}} b v r k^{\mathrm{d}} \mathrm{BC}_{1}$ 5-593 produced seedcoats with dark red kidney (garnet brown)/cartridge buff marbling, which is an allelic response to the $r k^{\mathrm{d}}$ gene in 'Thuringia'. Thus, 'Thuringia' carries the seedcoat genotype $t P C z j g b v^{\text {lae }} r k^{\mathrm{d}}$, where $z$ was formerly given the $d$ symbol (Bassett et al., 1999) and $j$ was formerly $L$ (Schreiber, 1940).

In an earlier paper, the allelism of $l^{\text {ers }}$ and $L$ was established (Bassett, 1997). Thus, $j, l^{\text {ers }}$, and $L$ are all alleles at one locus as demonstrated by the above data. Because the $J$ gene has precedence (Lamprecht, 1932), the recessive allele symbols must have the $j$ base. The question remaining is whether all three genes are identical or distinct alleles at $J$. The allelism test cross data above were all based on a genetic background of $t z$, but other data (Bassett, some unpublished) based on backgrounds with $T Z, T z$, and $t Z$ are available for consideration.

First consideration: data for the genetic background $T Z$. The genotype $T Z J$ expresses black unpatterned seed (Prakken, 1970). The genotype $T Z j$ has the margo phenotype of the genetic tester stock $j$ margo $\mathrm{BC}_{3}$ 5-593 (Bassett, 1996a). The genotype $T Z L$ (same as $T Z j$ ) expresses the margo pattern (Table 2). Genotype $T Z l^{\text {rers }}$ expresses unpatterned black (Bassett and Blom, 1991). Thus, the data from the $T Z$ background supports the hypothesis that $j$ and $L$ are identical alleles, but $l^{\text {ers }}$ is a different allele.

Second consideration: data for the $T z$ genetic background. Genotype $T z J$ has unpatterned black color (Prakken, 1970). Genotype $T z j$ expresses the margo $z$ pattern (without hilum ring or corona color) of the genetic tester stock $z j$ (margo $z$ ) $\mathrm{BC}_{3}$ 5-593 (Bassett, 1996a). Genotype $T z L$ (same as $T z j$ ) also expresses the margo $z$ pattern (Table 2). Genotype $T z l^{\text {ers }}$ expresses unpatterned black (Bassett and Blom, 1991). Thus, the data from the $T z$ background supports the same hypothesis regarding allelism of $J, L$, and $l^{\text {ers }}$ as did the $T Z$ genetic background.

Final consideration: data for the $t Z$ genetic background. Genotype $t Z J$ expresses either the self-colored seedcoat of the genetic tester stock $t$ black $\mathrm{BC}_{2}$ 5-593 (Bassett et al., 1999) or the expansa pattern with fibula arcs when the fibula arcs factor is present (Bassett, unpublished data). Genotype $t Z j$ expresses the marginata pattern of the genetic tester stock $t j$ marginata $\mathrm{BC}_{3}$ 5- 593 (Bassett 
Table 5. Common bean seed patterns produced in $\mathrm{F}_{1}$ progeny from $t z j^{\text {ers }}$ $\left(j^{\text {ers }}\right.$ formerly $l^{\text {ers }}$ ) white $\mathrm{BC}_{3} 5-593$ crossed with three genetic tester stocks.

\begin{tabular}{lll}
\hline \hline & \multicolumn{2}{c}{$\mathrm{F}_{1}$ progeny } \\
\cline { 2 - 3 } Tester stock & Genotype & Phenotype \\
\hline$z j($ margo $z) \mathrm{BC}_{3} 5-593$ & $T / t z / z j / j^{\text {ers }}$ & Reverse margo \\
$j$ margo $\mathrm{BC}_{3} 5-593$ & $T / t Z / z j / j^{\text {ers }}$ & Unpatterned black $^{\mathrm{y}}$ \\
$t z j$ marginata $\mathrm{BC}_{3} 5-593$ & $t / t z / z j / j^{\text {ers }}$ & White seedcoat $^{\mathrm{x}}$
\end{tabular}

zThe expected frequency of reverse margo (Fig. 3) in $\mathrm{F}_{2}$ is $0.0625=1 / 2$ $(T / t) \times 1 / 4(z / z) \times 1 / 2\left(j / j^{\text {ers }}\right)$.

yThe heterozygote $Z / z$ prevents reverse margo expression.

${ }^{\mathrm{x}}$ The homozygote $t / t$ prevents reverse margo expression.

et al., 1999). Genotype $t Z L$ also expresses the marginata pattern (Table 2). Genotype $t Z l^{\text {ers }}$ expresses self-colored seedcoats or expansa (Bassett and Blom, 1991). Thus, the data for four background genotype combinations of $T$ and $Z$ support the same hypothesis: the $j$ and $L$ alleles are identical, but $l^{\text {ers }}$ is a third allele at $J$. All the interactions described in the above considerations are summarized in Table 3. We propose the following symbols: $J$ (formerly the $l$ of Schreiber (1940)), $j$ (formerly the $L$ of Schreiber (1940)), and $j^{\text {ers }}$ (formerly the $l^{\text {ers }}$ of Bassett (1997).

The genetic tester stock $t z L$ white $\mathrm{BC}_{2}$ 5-593 was developed to transfer the $L$ gene from 'Thuringia' to 5-593, and test crosses with it also showed the allelism of $j$ and $L$ (Table 4 ). Those results have an advantage over test crosses with 'Thuringia' because the genetic background of 5-593 is well-investigated and is less vulnerable to false conclusions based on interactions with unknown genes. Test cross number 3 in Table 4 also gave support to the allelism hypothesis by giving the same genetic segregation whether the seed parent carried $j$ or $L$.

An interesting property of the $J$ and $j$ alleles is that $j$ is fully recessive to $J$ for color interactions (Prakken, 1970, 1972), but not fully recessive to $J$ for partly colored patterns with $t Z / Z, t Z / z$, and $t z / z$ (Tables 1 and 4). In fact, the $j$ effect with genotypes $t / t z / z J / j$ and $t / t Z / z J / j$ is almost dominant, i.e., nearly complete restriction of the colored pattern area. This leads to a anomalous dominance order of $j>J>j^{\text {ers }}$ with $t z$, whereas the dominance order with $T$ is $J=j^{\text {ers }}>$ $j$. Nevertheless, the gene symbols cannot be changed because of the precedence of $J$ dominance over $j$ for color and with $t Z$ for partly colored pattern.

Schreiber (1940) made no attempt to explore the seedcoat color genetics of his materials and, thus, did not discover the allelism of $J$ and $L$. Lamprecht (1934, see his crosses Nos. 32 and 38 and his Tables 2 and 3 ) made crosses segregating at $T, R, J, B$, and $V$, but he did not adequately analyze the $\mathrm{F}_{2}$ populations to discover the dual role of $J$ in seedcoat color and partly colored patterns.

REVERSE MARGo. Test cross $t z j{ }^{\text {ers }}$ white $\mathrm{BC}_{3} 5-593 \times j$ margo $\mathrm{BC}_{3}$ 5-593 segregated in $\mathrm{F}_{2}$ for a new seedcoat pattern, viz., reverse margo (Fig. 3), which had a frequency of 0.0429 (Table 4). The seedcoat background color illustrated in variable shades of gray (Fig. 3) has a silvery gray appearance in real seeds. The cross $t z j^{\text {ers }}$ white $\mathrm{BC}_{3} 5-593 \times z j$ (margo $z$ ) $\mathrm{BC}_{3} 5-593$ expresses the reverse margo pattern seedcoats in the $\mathrm{F}_{1}$ progeny, and the genotype for the pattern is thus known to be $T / t z / z j / j^{\text {ers }}$ (Table 5). The cross $t$ $z j^{\text {ers }}$ white $\mathrm{BC}_{3} 5-593 \times 5-593$ segregated in $\mathrm{F}_{2}$ for the genotype $T / t$ $z / z J / j^{\text {ers }}$, but no reverse margo pattern was observed (Bassett and Blom, 1991). Similarly, the cross $t z$ virgarcus $\mathrm{BC}_{3} 5-593 \times z j$ (margo z) $\mathrm{BC}_{3} 5-593$ segregated in $\mathrm{F}_{2}$ for the genotype $T / t z / z \mathrm{~J} / \mathrm{j}$, but no reverse margo pattern was observed (Bassett et al., 1999). Thus, genotype $j / j^{\text {ers }}$ is essential for reverse margo expression. The cross $t$ $z j^{\text {ers }}$ white $\mathrm{BC}_{3} 5-593 \times j$ margo $\mathrm{BC}_{3} 5-593$ expresses unpatterned black seedcoats (Table 5). Thus, genotype $z / z$ is essential for expression of reverse margo. Finally, the cross $t z j^{\text {ers }}$ white $\mathrm{BC}_{3} 5$ $593 \times t z j \mathrm{BC}_{3} 5-593$ expresses white seedcoat, demonstrating that

Table 6. $L$ marker $\mathrm{OL}_{525}$ classification of individual common bean cultivars and genetic stocks with known $J$ genotypes.

\begin{tabular}{|c|c|c|c|}
\hline$J$ Cultivars/genotypes & $\mathrm{OL}_{525}$ classification & $j$ Cultivars/genotypes & $\mathrm{OL}_{525}$ classification \\
\hline${\mathrm{BAT} 93^{2}}^{2}$ & Null & Citroen $^{\mathrm{w}}$ & Null \\
\hline Coulee $^{y}$ & Null & V0874 & Null \\
\hline Garnet $^{\mathrm{y}}$ & Null & $\mathrm{Opal}^{\mathrm{z}}$ & Null \\
\hline Hidasta $^{\mathrm{y}}$ & Null & Pariser Gelbe ${ }^{t}$ & Null \\
\hline Huetar $^{\mathrm{y}}$ & Null & Prakken $75^{\mathrm{z}}$ & Null \\
\hline Montcalm $^{y}$ & Null & Prim $^{s}$ & Null \\
\hline Rufus $^{y}$ & Null & V0400 r & Null \\
\hline $5-593^{y}$ & Null & Thuringia $^{z}$ & + \\
\hline Calima $^{\mathrm{z}}$ & + & & \\
\hline Jacobs Cattle ${ }^{y}$ & + & & \\
\hline Jalo EEP558 z & + & & \\
\hline Masterpiece ${ }^{\mathrm{z}}$ & + & & \\
\hline Redkloud $^{\mathrm{y}}$ & + & & \\
\hline V0687 & + & & \\
\hline Wagenaar ${ }^{w}$ & + & & \\
\hline Wax Digoin ${ }^{v}$ & + & & \\
\hline
\end{tabular}

${ }^{\mathrm{z}}$ Genotype at $J$ (Bassett, unpublished data).

${ }^{\mathrm{y}}$ Genotype at $J$ (Bassett, 1998b).

${ }^{x}$ Now PI 527771; genotype at $J$ (Lamprecht, 1961).

${ }^{\mathrm{w}}$ Genotype at $J$ (Prakken, 1972).

${ }^{\mathrm{v}}$ Genotype at $J$ (Lamprecht, 1932).

uNow PI 527808; genotype at $J$ (Bassett, unpublished data).

${ }^{\mathrm{t}}$ Genotype at $J$ (Lamprecht, 1934).

${ }^{\text {s} G e n o t y p e ~ a t ~} J$ (Bassett, 1999).

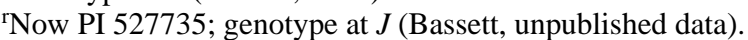


genotype $T / t$ is essential for reverse margo expression. Apparently, only one genotype $\left(T / t z / z j / j^{\text {ers }}\right)$ can express the reverse margo pattern, which is not true breeding. Attempts to classify and analyze the $F_{2}$ progeny from reverse margo $F_{1}$ parents failed because the segregation for the expected classes was badly disturbed, leading to estimates of $P<0.05$ for the obtained chi-square values (data not presented). However, the data obtained from selfing $F_{1}$ plants with reverse margo was instructive for selecting the right genetic tester stocks for crossing to produce the desired $\mathrm{F}_{1}$ genotypes in the reverse margo demonstration given above.

A COUPling RAPD marker For $j$. Concurrent with the genetic research, a molecular genetic study was performed to identify a RAPD marker linked to $j$ (formerly the $L$ gene of Schreiber, 1940). From the $\mathrm{F}_{2}$ progeny of the cross 'Thuringia' $\mathrm{x} t z$ virgarcus $\mathrm{BC}_{3} 5$ 593 , bulk DNA samples consisting of white $(t z \mathrm{j} /-)$ and virgarcus $(t$ $z J$ ) individuals were developed. The $\mathrm{F}_{2}$ segregation ratio fit the expected 3 white 1 virgarcus ratio $\left(\chi^{2}=1.07 ; P=0.30\right)$. Polymerase chain reaction (PCR) analysis (Brady et al., 1998) of these DNA bulks was performed using a series of oligonucleotide primers, and Operon Technologies, Alameda, Calif., primer L4 generated a 525 base pair fragment in the white seedcoat bulk not observed in the virgarcus bulk. This suggested the primer was linked to the $j$ allele. The $\mathrm{F}_{2}$ population was subsequently screened, and a single recombinant event was observed. The linkage distance between $j$ and marker $\mathrm{OL}_{525}$ was estimated to be $1.2 \mathrm{cM}$.

To further test the linkage relationship between marker OL $4_{525}$ and the various $J$ alleles, $\mathrm{F}_{2}$ progeny from the cross $t z J$ bip bipunctata $\mathrm{BC}_{3} 5-593 \times t z j^{\text {ers }}$ Bip white $\mathrm{BC}_{3} 5-593$ were analyzed. In the North Dakota greenhouse where this population was grown, the bipunctata class $(t z J /$ - bip) could not be distinguished from the $\left(t z J / j^{\text {ers }}\right.$ Bip) weak virgarcus class. Therefore, the three remaining expected phenotypic classes - virgarcus, weak virgarcus, and white - are expected to segregate in a 1:2:1 ratio, respectively. Statistical analysis confirmed this expectation $\left(\chi^{2}=0.59, P=0.74\right)$. PCR analysis with the L4 primer revealed that, except for three recombinant events, the appropriate sized fragment appeared in DNA samples from those individuals containing the $j^{\text {ers }}$ allele (weak virgarcus and white) and was absent from individuals with $J / J$ (virgarcus). In this population, the linkage distance between $j$ and $\mathrm{OL}_{525}$ was estimated to be $4.7 \mathrm{cM}$. Because the RAPD marker was in coupling phase with both the $j$ and $j$ ers alleles, we hypothesize that the two alleles may be more similar to each other by ancestry than they are to the $J$ allele. This result is consistent with the observation that both of these alleles have similar phenotypic effects, viz., both strongly restrict the extent of colored seedcoat pattern development, whereas $J$ has no restriction effect on colored pattern expression.

Twenty-four genotypes with known alleles at $J$ were screened for the presence or absence of the OL $4_{525}$ marker (Table 6). As expected, eight $J$-carrying genotypes lacked the band. Except for 'Montcalm', each of these individuals are from the Middle American gene pool. On the other hand, a second group of eight $J$-carrying individuals contained the band. At least five of those individuals (and possibly seven) are of Andean origin (gene pool). Given this result, we can conclude that the marker, as currently described, has limited usefulness. Others have also discovered markers that are gene-pool specific in Phaseolus vulgaris (Johnson et al., 1995; Miklas et al., 1993). A procedure that may remedy this limitation is to sequence the marker fragment from multiple genotypes and design a more informative set of primers for this genetic locus.

\section{Literature Cited}

Bassett, M.J. 1994a. The margo (mar) seed coat character and the tmar interaction in common bean. J. Hered. 85:404-407.

Bassett, M.J. 1994b. The griseoalbus (gray-white) seedcoat color is controlled by an allele $\left(p^{\text {gri }}\right)$ at the $P$ locus in common bean. HortScience 29:1178-1179.

Bassett, M.J. 1995. The dark corona character in seedcoats of common bean cosegregates with the pink flower allele $v^{\text {lae }}$. J. Amer. Soc. Hort. Sci. 120:520 522.

Bassett, M.J. 1996a. The margo (mar) seedcoat color gene is a synonym for the joker locus in common bean. J. Amer. Soc. Hort. Sci. 121:1028-1031.

Bassett, M.J. 1996b. Inheritance of the partly colored seedcoat pattern, bipunctata, in common bean. J. Amer. Soc. Hort. Sci. 121:1032-1034.

Bassett, M.J. 1997. Allelism tests involving two genes, ers and ers-2, that restrict partly colored seedcoat expression in common bean. J. Amer. Soc. Hort. Sci. 122:802-807.

Bassett, M.J. 1998a. The genotype for seed coat color and pattern of breeding line 5-593, 1998. Annu. Rpt. Bean Improvement Coop. 41:127-128.

Bassett, M.J. 1998b. A test cross protocol for determining the genotype of dark red seedcoat colors in common bean. J. Amer. Soc. Hort. Sci. 123:1048-1952.

Bassett, M.J. 1999. The seedcoat color genotype of 'Prim' and the Manteca and Coscorrón market classes of common bean. HortScience 34:336-337.

Bassett, M.J. 2000. A test cross protocol for determining the seedcoat genotype at the $C$ locus in common bean. HortScience 35:286-289.

Bassett, M.J. and A. Blom 1991. A new genotype for white seed coat discovered in 'Early Wax' snap bean. J. Amer. Soc. Hort. Sci. 116:131-136.

Bassett. M.J. and P.E. McClean. 2000. A brief review of the genetics of partly colored seed coats in common bean. Annu. Rpt. Bean Improvement Coop. 43:99-101.

Bassett, M.J., C. Shearon, and P.E. McClean. 1999. Allelism found between two common bean genes, hilum ring color $(D)$ and partly colored seedcoat pattern (Z), formerly assumed to be independent. J. Amer. Soc. Hort. Sci. 124:649-653.

Brady, L., M.J. Bassett, and P.E. McClean. 1998. Molecular markers associated with $T$ and $Z$, two genes controlling partly colored seed coat patterns in common bean. Crop Sci. 38:1073-1075.

Johnson, E., P.N. Miklas, J.R. Stavely, and J.C. Martinez-Cruzado. 1995. Coupling- and repulsion-phase RAPDs for marker-assisted selection of PI 181996 rust resistance in common bean. Theor. Appl. Genet. 90:659-664.

Lamprecht, H. 1932. Beiträge zur Genetik von Phaseolus vulgaris, Zur Vererbung der Testafarbe. Hereditas 16:169-211.

Lamprecht, H. 1934. Zur Genetik von Phaseolus vulgaris. VII. Zwei weitere Gene für Sameneigen-schaften, Cor und Fast. Hereditas 19:163-176.

Lamprecht, H. 1940. Zur Genetik von Phaseolus vulgaris. XVI. Weitere Beiträge zur Vererbung der Teilfarbigkeit. Hereditas 26:277-291.

Lamprecht, H. 1961. Die Vererbung der rezessiv roten Testafarbe von Phaseolus. Agr. Hort. Genet. 19:344-359.

Lander, E.S., P. Green, J. Abrahamson, A. Barlow, M.J. Daly, S.E. Lincoln, and L. Newburg. 1987. MAPMAKER: An interactive computer package for constructing primary genetic linkage maps of experimental and natural populations. Genomics 1:174-181

Leakey, C.L.A. 1988. Genotypic and phenotypic markers in common bean, p. 245-327. In: P. Gepts (ed.). Genetic resources of Phaseolus beans. Kluwer Academic Press, Boston.

Lincoln, S., M. Daly, and E. Lander. 1992. Constructing genetic maps with MAPMAKER/EXP 3.0. Whitehead Inst. Tech. Rpt. $3^{\text {rd }}$ edition. Whitehead Inst., Cambridge, Mass.

Miklas, P.N., J.R. Stavely, and J.D. Kelly. 1993. Identification and potential use of a molecular marker for rust resistance in common bean. Theor. Appl. Genet. 85:745-749.

Prakken, R. 1970. Inheritance of colour in Phaseolus vulgaris L. II. A critical review. Meded. Landbouwhogeschool Wageningen 70-23:1-38.

Prakken, R. 1972. Inheritance of colours in Phaseolus vulgaris L. III. On genes for red seedcoat colour and a general synthesis. Meded. Landbouwhogeschool Wageningen 72:1-81.

Schreiber, F. 1940. Die Genetik der Teilfarbung der Bohnensamen (Phaseolus vulgaris). Zeitschr. Ind. Abst. Vererbungsl. 78:59-114. 